\title{
両側卵巣チョコレート襄胞症例における腹腔鏡手術の術後成績について
}

医療法人格医会 可世木病院 ${ }^{1)}$ 、藤田保健衛生大学医学部産婦人科教室 ${ }^{2)}$ 中村あずみ ${ }^{1)}$ 、廣田 稕㝨、西尾永司 ${ }^{2)} 、$ 宮田雅子 ${ }^{2)}$ 、西澤春紀 ${ }^{2)} 、$ 安江 朗 ${ }^{2)}$ 、松岡美杉 ${ }^{2}$ 、塚田和彦 ${ }^{2}$ 、宇田川康博 ${ }^{2}$

\section{Outcomes of laparoscopic surgery for bilateral ovarian chocolate cysts, with emphasis on recurrence, fertility, and ovarian reserve}

\author{
Azumi Nakamura $^{1)}$, Yutaka Hirota ${ }^{2)}$, Eiji Nishio ${ }^{2)}$, Masako Miyata ${ }^{2)}$, Haruki Nishizawa ${ }^{2)}$, \\ Akira Yasue $^{2)}$, Misugi Matsuoka ${ }^{2}$, Kazuhiko Tsukada ${ }^{2)}$, Yasuhiro Udagawa ${ }^{2)}$ \\ Department of Obstetrics and Gynecology, Kaseki Hospital ${ }^{1}$ \\ Department of Obstetrics and Gynecology, Fujita Health University School of Medicine ${ }^{2)}$
}

\begin{abstract}
Objective: We conducted postoperative follow-up of patients with bilateral ovarian chocolate cysts, focusing on rates of recurrence, potential to conceive, and degree of ovarian reserve.

Methods: A total of 128 patients diagnosed with bilateral ovarian chocolate cysts were studied during a 9-year period. Any patient seen postoperatively for six months or more was included in the study. Of this cohort, 21 underwent bilateral cystectomy, while bilateral fenestration and coagulation was performed for the remainder $(n=107)$.

Results: The recurrence rate was $4.7 \%$ (6/128), with all instances of recurrence limited to the bilateral fenestration and coagulation technique The mean period from surgery to recurrence was 12.5 months (range, 10-31 months). The recurrence rate by surgical procedure was $0 \%(0 / 21)$ for bilateral cystectomy and $5.6 \%(6 / 107)$ for bilateral fenestration and coagulation. Seventeen of 40 (42.5\%) patients became pregnant in the study time frame (12 spontaneous cycles, 3 clomiphene cycles, and 2 IVF-ET cycles). We also selectively examined subjects under the age of 40 years (115/128) whose menstrual cycles had been normal prior to surgery. The rate of postoperative menstrual disorders was $22.2 \%$ (4/18 cases) for bilateral cystectomy and $4.1 \%$ (4/97 cases) for bilateral fenestration and coagulation ( $\mathrm{p}=0.0055)$.

Discussion: Laparoscopic fenestration and coagulation, rather than cystectomy, may be a preferable treatment for bilateral chocolate ovarian cysts in terms of preserving fertility and ovarian reserve.
\end{abstract}

Key Words: ovarian chocolate cyst, recurrence rate, ovarian reserve

\section{諸言}

女性のライフスタイルの変化により子宮内膜 症一特に、卵巣チョコレート襄胞を取り扱う機会 が確実に増加している。卵巣チョコレート襄胞は 生殖年齢婦人に好発する疾患であり、近年、手術 治療においては腹腔鏡手術を選択する施設が累増 している。その理由は、子宮内膜症が示す多彩な 病変は肉眼よりもむしろ腹腔鏡でこそ詳細に観察
可能で、子宮内膜症取り扱い規約でも婦人科医は 腹腔鏡を大いに利用すべきであると記されている ことからも首肯される1)。現に、当施設での最近 5 年間（2005-2009年）での卵巣チョコレート襄 胞の腹腔鏡手術実施数は381例（腹腔鏡手術総数に 占める頻度 $30.7 \%$ ）であり、卵巣疾患に対する腹 腔鏡手術の中で最も実施頻度の高い術式となって いる。一方、両側卵巣チョコレート震胞の手術症 例では臨床妊娠率、生産率は明らかに減少するこ 
とが示されており、若年婦人ではその取り扱いに 細心の注意を払う必要がある2)。そこで本稿では、 当施設における「両側」卵巣チョコレート襄胞症 例の腹腔鏡手術の予後一特に、再発、妊娠、卵巣 機能に焦点を絞り検討した。

\section{対象および方法}

対象は、2001年 1 月より2009年10月までに両側 卵巣チョコレート襄胞に対し同一手法の卵巣保存 手術を実施しかつ術後 6 ケ月以上経過観察が可能 であった128例－両側囊胞摘出術21例、両側囊胞壁 燒灼術107例とした（片側付属器切除や左右卵巣に 異なった手術操作を加えたものは対象から除外し た）。手術操作では、卵巣以外の子宮内膜症病 変一主に腹膜病変には可及的にバイポーラで焼灼 を加え、子宮および付属器周囲の癒着は可能な限 り剥離操作を実施、加えて 31 前後の生理的食塩 水で骨盤内洗浄を行った。尚、本稿での「再発」 は術後の経胵超音波断層法ならびにMRIにて卵巣 チョコレート襄胞（直径 $20 \mathrm{~mm}$ 以上）と診断した ものを再発例とし、「月経異常例」とは術前に月 経周期が整であったものが術後 2 ケ月以上無月経 を呈したものとした。統計処理はChi-square test およびMann-Whitney testを用い、数值は平均值 （range）ないしは標準誤差で表記した。

\section{成 績}

【術後の再発に関する検討】

対象128例における術後の平均観察期間（range） は25.6（ 6 ～82）ケ月であった。両側囊胞摘出術 例、両側囊胞壁焼灼術例の平均年齢は、各々 $33.3 \pm 1.1$ 歳、 $32.9 \pm 0.5$ 歳、以下同様に平均最大囊 胞径；65.6 $\pm 5.6 \mathrm{~mm} 、 55.6 \pm 2.6 \mathrm{~mm}$ 、術前CA125 值; $86.1 \pm 20.4 \mathrm{U} / \mathrm{ml} 、 68.1 \pm 7.0 \mathrm{U} / \mathrm{ml}$ 、ASRMスコ ア；69.4 \pm 5.4点、 $70.9 \pm 2.7$ 点で両者間の臨床的背 景因子に差異は認めなかった。術後の再発率は、 4.7\%（6/128例）であり、再発までの平均観察期 間は12.5（10～31）ケ月であった。再発を認めた 6 例の手術術式は共に両側卵巣囊胞壁焼灼術施行例 で、同術式における再発例と非再発例の比較検討 では臨床所見に差異は認めなかった（表 1 )。ま た手術術式別の再発率を検討すると、両側囊胞摘 出術 $0 \%(0 / 21$ 例）、両側囊胞壁焼灼術 $5.6 \%$ (6/107例) となり両術式間に差異を認めなかった $(\mathrm{p}=0.5844)$ 。
表 1 両側囊胞壁焼灼術における再発例の検討

\begin{tabular}{lccc}
\hline & 再発例 & 非再発例 & \\
\hline 症例数 & 6 & 101 & \\
& & & \\
年齢(歳) & $33.5 \pm 1.8$ & $32.0 \pm 0.5$ & N.S. \\
輁胞最大径 $(\mathrm{mm})$ & $54.3 \pm 6.0$ & $55.7 \pm 2.7$ & N.S. \\
術前CA125值 $(\mathrm{U} / \mathrm{ml})$ & $64.6 \pm 17.7$ & $68.3 \pm 7.4$ & N.S. \\
ASRMスコア(点) & $79.1 \pm 9.8$ & $70.3 \pm 2.8$ & N.S. \\
& & & \\
\hline
\end{tabular}

【術後の妊娠例に関する検討】

挙児希望を明確にし得た40例中17例（42.5\%）に 妊娠が成立した。その内訳は、自然妊娠例 12 例、 クロミフェン-hCG療法例 3 例、ART施行例 2 例で あった。術後の平均妊娠待機期間は9.9（1～34） ケ月であり、妊娠例の $76.5 \%$ は術後 1 年以内の妊 娠であった。妊娠例と非妊娠例の比較検討では、 両者間の臨床的背景因子に差異はなかった(表 2 )。 また妊娠例の手術術式の内訳（妊娠率）は、両側 囊胞摘出術 $3 / 6$ 例 $(50.0 \%)$ 、両側囊胞壁焼灼術 14/34例（41.2\%）であり、両術式間での妊娠率に 差異は認めなかった。

表 2 妊娠例と非妊娠例の比較

\begin{tabular}{lccc}
\hline & 妊娠例 & 非妊娠例 & \\
\hline 症例数 & 17 & 23 & \\
& & & \\
年齢(歳) & $29.2 \pm 0.9$ & $31.2 \pm 1.0$ & N.S. \\
霊胞最大径 $(\mathrm{mm})$ & $58.1 \pm 6.1$ & $54.0 \pm 3.7$ & N.S. \\
術前CA125值 $(\mathrm{U} / \mathrm{ml})$ & $78.1 \pm 16.1$ & $95.0 \pm 17.2$ & N.S. \\
ASRMスコア(点) & $63.3 \pm 4.9$ & $75.0 \pm 6.2$ & N.S. \\
& & &
\end{tabular}

$\operatorname{MEAN} \pm$ SEM

【術後の卵巣機能に関する検討】

外来でのフォローアップ時に 2 カ月以上の無月 経を呈した症例を $9 / 128$ 例（7.0\%）に認めた。こ の内の 7 例は自然経過観察ないしはEstrogen progesterone cyclic therapy（EPCT）により正 常月経周期を回復したが、残りの 2 例は手術後か ら高ゴナドトロピン血症が持続し種々のホルモン 治療に抵抗性を示し自然排卵周期の回復が困難で あった（表 3 )。次に手術術式が術後の卵巣機能 に及ぼす影響を検討した。ここでは加齢による卵 巣機能への影響を考慮し、対象128例の中から40歳 未満の症例で後方視的に術前の月経周期が整であ ることを確認できた115例を抽出し検討した。115 


\begin{tabular}{|c|c|c|c|c|c|c|c|}
\hline & \multirow[b]{2}{*}{ 年齢 } & \multicolumn{3}{|c|}{ 最大囊胞径(mm) } & \multicolumn{2}{|c|}{ 術式 } & \multirow[b]{2}{*}{ 転帰 } \\
\hline & & $\mathrm{G} / \mathrm{P}$ & 左 / 右 & ASRM & 左 & 右 & \\
\hline \multicolumn{5}{|c|}{ 月経が再開した月経異常例 } & \multirow{8}{*}{$\begin{array}{l}\text { 摘出 } \\
\text { 焼昫 } \\
\text { 焼昫 } \\
\text { 焼灼 } \\
\text { 暁灼煥出 } \\
\text { 出 }\end{array}$} & \multicolumn{2}{|r|}{ 月経再開までの期間 } \\
\hline 症例 1 & 37 & $2 / 2$ & $91 / 10$ & 51 & & 摘出 & 2ヶ月 \\
\hline 症例 2 & 27 & $0 / 0$ & $40 / 133$ & 62 & & 焼灼 & 4ヶ月 \\
\hline 症例 3 & 33 & $0 / 0$ & $80 / 70$ & 114 & & 焼灼 & 6ケ月 \\
\hline 症例 4 & 35 & $2 / 2$ & $58 / 29$ & 90 & & 焼灼 & 6ヶ月 \\
\hline 症例 5 & 41 & $0 / 0$ & $90 / 15$ & 130 & & 焼灼 & 6ヶ月 \\
\hline 症例 6 & 28 & $0 / 0$ & $59 / 42$ & 122 & & 摘出 & 10ヶ月 \\
\hline 症例 7 & 29 & $0 / 0$ & $41 / 51$ & 56 & & 摘出 & 24 ケ月 \\
\hline \multicolumn{8}{|c|}{ 治療抵抗性の卵巣性無月経 } \\
\hline 症例 8 & 33 & $0 / 0$ & $59 / 87$ & 98 & 摘出 & 摘出 & \multirow{2}{*}{ EPCT中 } \\
\hline 症例 $9^{*}$ & 37 & $1 / 1$ & $58 / 37$ & 58 & 焼灼 & 焼灼 & \\
\hline
\end{tabular}

* 症例9：チョコレート囊胞に対して過去3回手術治療既往のある難治性症例

例の内訳は両側囊胞摘出術18例、両側囊胞壁焼灼 術97例であり、前者および後者における月経異常 発現頻度は、各々 $4 / 18$ 例 $(22.2 \%) 、 4 / 97$ 例 $(4.1 \%)$ であり、囊胞壁焼灼術より囊胞摘出術において月 経異常の発現頻度が有意に高いことが示された （p=0.0055）（表 $4 ） 。$

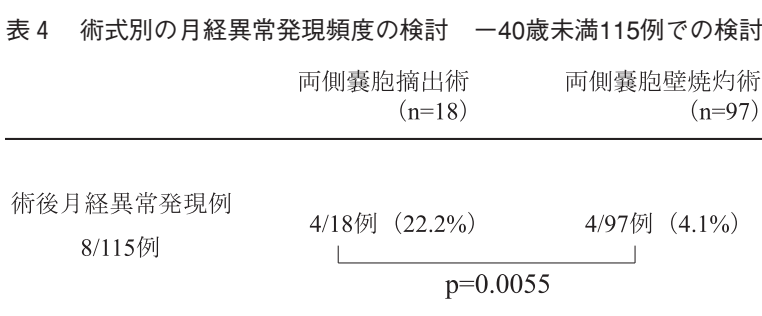

\section{考察}

卵巣チョコレート震胞に対する薬物治療は、新 たな展開を迎えている。それは、従来よりのダナ ゾールやGnRHアゴニストに加え、新しい第 4 世 代プロゲスチンであるジエノゲスト（ディナゲス ト $\left.{ }^{\circledR}\right)$ の開発と低容量ピル (ルナベル $\left.{ }^{\circledR}\right)$ の保険収 載であり、更にはGnRHアンタゴニストやアロマ ターゼ阻害薬も今後の臨床応用が期待されている。 しかし、これら薬物治療には限界があり、腹腔内 の観察と治療を同時に行える腹腔鏡手術は子宮内 膜症治療の重要な部分を占めている。

卵巣保存手術後の再発については、若年者、 ASRMスコア高值がリスク因子であるという報告 ${ }^{3)}$ や襄胞径が大きく先行薬物治療がリスク因子であ り、術後妊娠が再発率を下げるという報告がある が4)、我々の検討では上記臨床的背景因子に差異 はなく、再発に関する特定因子の同定には至らな
かった。卵巣保存手術は囊胞摘出術と囊胞壁焼灼 術に大別される。子宮内膜症取り扱い規約には囊 胞摘出術の方が襄胞壁焼灼術に比べ再発率が低い ことが記載されているが、一方で術式選択と術後 の再発に関しては両術式の是非を論議する多くの 論文が存在する ${ }^{3-7)}$ 。今回の検討でも術後再発に関 しては、両術式の優位性を明らかにすることはで きなかった。我々の術後再発率は、「両側発生」の 卵巣チョコレート襄胞症例にも関わらず $4.7 \%$ と低 率であった。我々は再発を防ぐ手術手法として大 事な点は、卵巣表面や内性器周囲の腹膜病変の観 察を詳細に行い、チョコレート囊胞以外の腹膜病 変についても腹腔鏡手術の利点を活用し（拡大視 による詳細な腹膜病変の観察と同定が可能）根気 よく丁寧に病巣を除去し骨盤内を 31 前後の洗浄 液で大量洗浄することが肝要であり、むしろこの ことが低い再発率を担保する要因となっているの ではないかと考えている。

挙児希望のある卵巣チョコレート震胞症例に対 しては、薬物治療/手術治療のどちらを優先すべき かは議論の余地がある。しかし、子宮内膜症は進 行性の疾患であること、そして今回の検討結果 挙児希望者の $42.5 \%$ が平均妊娠待機期間 9.9 个月で 妊娠に至り、そのうち $76.5 \%$ が術後 1 年以内に妊 娠成立したことから勘案すると、挙児希望のある 卵巣チョコレート襄胞症例には積極的な腹腔鏡手 術を優先すべきと思われた。術式にも窮余の選択 が迫られるが、囊胞摘出術/囊胞壁焼灼術における 妊娠率の差異に一定の見解はなく ${ }^{6-9)}$ 、我々の検討 でも術式選択が妊娠に与える影響は少ないものと 思われた。しかし、妊孕性温存を優先する若年婦 人には、妊娠率だけでなく『術後卵巣機能』も考 慮した術式の選択が必要不可欠である。術後の卵 
巣機能に関しては、囊胞摘出術では術後の原始卵 胞数の減少 ${ }^{10,11)}$ や不妊治療での排卵誘発剤に対す る不応性が指摘されている ${ }^{12)}$ 。その一方で摘出囊 胞壁に付着していた卵胞数が10個以下の症例が 80\%以上であったことから、手術操作自体が術後 の卵巣機能に及ぼす影響は少ないとする報告や ${ }^{13)}$ 、 囊胞壁焼灼術においてはdebrisにより病変部の同 定が困難なため内腔を全面焼灼する必要があり、 その熱損傷により卵巣組織が広範なダメージを受 け原始卵胞も損なわれる可能性も指摘され、術後 の卵巣機能に関しては囊胞摘出術と差異がないと いう報告もある ${ }^{14)}$ 。その他、卵巣周囲癒着の高度 症例では、卵巣血流の低下が卵巣機能に影響を及 ぼす可能性も示唆されている ${ }^{15)}$ 。

今回の我々の解析では、囊胞壁燒灼術が囊胞摘 出術より月経異常の発現頻度が有意に少なく、卵 巣機能の温存に関しては襄胞壁焼灼術の優位性が 示された。そこで以下では、上記知見をもとに卵 巣チョコレート襄胞に対する手術手技（囊胞摘出 術および襄胞壁焼灼術）が卵巣機能へ及ぼす影響 を考えてみた。囊胞摘出術では、症例毎の差異は あるものの卵巣実質組織の減少と囊胞壁摘出操作 にともなう原始卵胞の喪失があること、さらには 囊胞摘出にともなう止血操作一熱エネルギーソー スによる止血操作は必須な処置であり、この止血 操作による熱損傷が残存卵巣組織の血流への悪影 響と原始卵胞のさらなる茄失を引き起し術者の巧 拙によりこの傾向が助長されることが危惧される。 その一方、囊胞壁焼灼術では囊胞壁焼灼にともな う卵巣実質への熱損傷は回避できないが、霊胞摘 出操作を行わないため卵巣実質の目減り（囊胞摘 出術では摘出囊胞壁が予想以上に厚く十分な卵巣 組織を温存できないこともしばしば経験する）や 囊胞壁摘出操作にともなう原始卵胞の喪失がなく、 囊胞壁を焼灼するのみなので術者の巧拙が卵巣予 備能に及ぼす影響も少ないことなど卵巣機能温存 の観点から有利な手法と思われた。

\section{結 語}

両側卵巣チョコレート襄胞症例の手術治療にお いては術後の卵巣機能低下に十分留意する必要が あるものと思われた。特に医原性のPOF発症は回 避すべき重要課題であり、今後は術前・術後での Anti-mullerian hormone等の卵巣予備能評価を行 い手術治療の個別化も検討していきたいと考えて いる。
本論文の要旨は、第 48 回日本産科婦人科内視鏡 学会において発表した。

\section{文献}

1) 子宮内膜症取扱い規約 第2 部治療編 - 診療編、2010.

2 ) Somiglianas E, et al : The presence of ovarian endometriomas is associated with a reduced responsiveness to gonadotropins. Fertil Steril 2008 ; 86 : 192-196.

3 ) Kikuchi I, et al. : Reccurrence rate of endometriomas following a laparoscopic cystectomy. Acta Obstet Gynecol Scand 2006 ; 85 : 1120-1124.

4 ) Koga K, et al. : Recurrence of ovarian endometrioma after laparoscopic excision. Hum Reprod 2006 ; 21 : 2171-2174.

5 ) Saleh A, Tulandi $T$ : Reoperation after laparoscopic treatment of ovarian endometriomas by excision and by fenestration. Fertil Steril $1999 ; 72: 322-324$.

6 ) Hemmings R, Bissonnette F, Bouzayen R : Results of laparoscopic treatments of ovarian endometriomas laparoscopic ovarian fenestration and coagulation. Fertil Steril $1998 ; 70: 527-529$.

7 ) Beretta P, et al. : Randomized clinical trial of two laparoscopic treatment of endometriomas:cystectomy versus drainage and coagulation. Fertil Steril $1998 ; 70$ : 1176-1180

8) Hart RG, et al. : Excisional surgery versus ablative surgery for ovarian endometriomata. Cochrane Database Syst Rev 2005 ; 20 : CD004992.

9 ) Alborzi S, et al. : A prospective, randomized study comparing laparoscopic ovarian cystectomy versus fenestration and coagulation in patients with endometriomas. Fertil Steril 2004 ; 82 : 1633-1637.

10) Donnez J, Wyns C, Nisolle M : Does ovarian surgery for endometriomas impair the ovarian response to gonadotropin? Fertil Steril $2001 ; 76: 662-665$.

11) Candiani $M$, et al. : Ovarian recovery after laparoscopic enucleation of ovarian cysts: Insights from echographic short-term postsurgical follow-up. J Minim invasive Gynecol 2005 ; 12 : 409-414.

12) Loh FH, et al. : Ovarian response after laparoscopic ovarian cystectomy for endometriotic cysts in 132 monitored cycle. $1999 ; 72: 316-321$.

13）小林優子、他：子宮内膜症と不妊、産婦人科治療、 $2008 ; 96: 261-265$.

14) Alborzi S, et al : A comparison of follicular response of ovaries to ovulation induction after laparoscopic ovarian cystectomy or fenestration and coagulation versus normal ovaries in patients with endometrioma. Fertil Steril 2007 ; 88 : 507-509.

15）詠田由美、他：卵管因子を有する子宮内膜症とIVFET治療成績、エンドメトリオーシス研会誌、1998; 19 : 68-73. 